\title{
BioéthiqueOnline
}

\section{Dear DTCA, Please Don’t Deceive Me, Don’t Play on My Fantasy}

\section{Jean-Christophe Bélisle-Pipon}

Volume 5, 2016

URI : https://id.erudit.org/iderudit/1044293ar

DOI : https://doi.org/10.7202/1044293ar

Aller au sommaire du numéro

Éditeur(s)

BioéthiqueOnline

ISSN

1923-2799 (numérique)

Découvrir la revue

Citer cet article

Bélisle-Pipon, J.-C. (2016). Dear DTCA, Please Don’t Deceive Me, Don’t Play on My Fantasy. BioéthiqueOnline, 5. https://doi.org/10.7202/1044293ar
Résumé de l'article

Face à la publicité de médicaments, que pouvons-nous? Est-ce que la publicité directes au consommateur (DTCA) est bienfaisant à notre égard en présentant de façon objective un produit ou cherche-t-elle à nous convaincre que c'est définitivement le bon traitement, la bonne approche, pour nous soigner? À travers cette chanson, le but est de faire vivre l'expérience d'un patient qui est sujet à de la publicité, en intégrant dans les strophes les principaux enjeux éthiques que cela soulève.
Droits d'auteur @ ㄱ-C Bélisle-Pipon, 2016

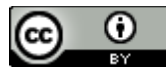

Ce document est protégé par la loi sur le droit d'auteur. L'utilisation des services d'Érudit (y compris la reproduction) est assujettie à sa politique d'utilisation que vous pouvez consulter en ligne.

https://apropos.erudit.org/fr/usagers/politique-dutilisation/ 


\title{
Dear DTCA, Please Don't Deceive Me, Don't Play on My Fantasy
}

\author{
TRAVAIL CRÉATIF / CREATIVE WORK
}

Jean-Christophe Bélisle-Pipon ${ }^{1,2}$

Reçu/Received: 22 Aug $2016 \quad$ Publié/Published: 7 Oct 2016

Éditeurs/Editors: Vincent Couture \& Aliya Affdal

2016 J-C Bélisle-Pipon, Creative Commons Attribution 4.0 International License

\begin{abstract}
Résumé
Face à la publicité de médicaments, que pouvons-nous? Est-ce que la publicité directes au consommateur (DTCA) est bienfaisant à notre égard en présentant de façon objective un produit ou cherche-t-elle à nous convaincre que c'est définitivement le bon traitement, la bonne approche, pour nous soigner? À travers cette chanson, le but est de faire vivre l'expérience d'un patient qui est sujet à de la publicité, en intégrant dans les strophes les principaux enjeux éthiques que cela soulève.
\end{abstract}

\section{Mots clés}

campagne de marketing, direct aux consommateurs, familiarisation aux médicaments, industrie pharmaceutique, information, médicaments d'ordonnance, chanson, méprise thérapeutique, transfert de connaissances par l'art

\section{Summary}

In the face of drugs advertising, what can we do? Is Directto-Consumer Advertising (DTCA) designed to be beneficial by objectively presenting a product or are they rather seeking to convince us that their product is patently good? Through this song, the goal is to live the experience of a patient who is subject to drug advertising, by integrating into the stanzas the main ethical issues raised by advertising.

\section{Keywords}

advertising, art-based knowledge transfer, direct-toconsumer, drug familiarization, information, marketing campaign, pharmaceutical industry, prescription drugs, song, therapeutic misconception

Affiliations des auteurs / Author Affiliations

${ }^{1}$ Bioethics Program, School of Public Health, Université de Montréal, Montréal, Québec, Canada

${ }^{2}$ Institut de recherche en santé publique de l'Université de Montréal, Montréal, Québec, Canada

\section{Correspondance / Correspondence}

Jean-Christophe Bélisle-Pipon, jean-christophe.belisle.pipon@umontreal.ca

\section{Remerciements}

L'auteur tient à remercier Victoria Doudenkova pour ses commentaires sur le présent papier ainsi que pour les longues conversations qui ont mené au développement d'une réflexion critique par rapport à son thème de recherche. L'auteur est soutenu par une bourse doctorale du Fonds de recherche du Québec - Santé (FRQS) \& I'Unité SOUTIEN-SRAP du Québec.

\section{Conflit d'intérêts}

Bélisle-Pipon est co-fondateur et ancien éditeur exécutif de BioéthiqueOnline.

\section{Acknowledgements}

The author would like to thank Victoria Doudenkova for her insightful comments on this piece and for long conversations that led to a broader critical thinking in relation to the research theme. The author is supported by a PhD scholarship from the Fonds de recherche du Québec - Santé (FRQS) \& the Unité SOUTIEN-SRAP du Québec.

\section{Conflicts of Interest}

Bélisle-Pipon is co-founder and former executive editor of BioéthiqueOnline. 
It's just one, in a million minds, that feel the way, the way I do. It's just one, in a million minds, that feel the way, the way I do.

Am I the wrong man, am I not of great merit?

Do I feel care like all of the others or is this feeling only mine?

Are you my relieving cure? Is it an obvious claim?

I'm living like a lion pretending I'm healthy but we know it's only a big lie.

Am I one heartbeat away from receiving a redemptive speech to my health and believing that care was a cause praiseworthy while seeing it's all part of a scheme?

Fighting is futile, but I can't concede, while interior beliefs alert me of their corporate deceitful practices which have grown from a relentless pursuit for profit.

We're vuln'rable, we can't think through;

Faith in their meds, as in their ads.

A poison's brain, pass through my mind.

Look at the frame, around the lie.

Trust has a form, too convincing;

I need defence, against their claims.

We can't go far, we know nothing,

About their meds, about their lust.

It's just one, in a million minds,

that suffers the way, the way I do.

It's just one, in a million minds,

that suffers the way, the way I do.

\section{Epilogue}

As I was listening to the song "Her Fantasy" by Matthew Dear ${ }^{1}$ while working on my thesis, I got carried away by the music and I started to associate the metaphors of the search for love and the game of seduction in the song to my doctoral area of research: direct-to-consumer communications (DTCC) of prescription drugs. It seemed to me that Dear's song allowed me to draw interesting parallels with DTCC, especially in relation to the ethical issues surrounding DTCC. To achieve this, I preserved the song's structure, and the idea of a banal main character who could be anyone (not unhealthy per se, but neither a paragon of healthy lifestyles), while reworking the text so that it evokes and presents my doctoral research problem, all along maintaining decent adequacy with the melody.

The ethics of direct communications from pharmaceutical companies to consumers is a particularly relevant theme given that DTCA can affect virtually all patients in every country, in one way or another, thus raising its share of ethical issues. Despite the variability of national health policies on DTCC and the degree of regulatory permissiveness, at least one type of communication is permitted in each country: either under a promotional or informational form. And most often, DTCC uses mass media thus ensuring that such messages can easily reach patients. DTCC includes two large families of communications to patients: DTC advertising (DTCA) and DTC information (DTCI). For instance, in the most DTCC permissive countries (i.e., the US and New Zealand), consumers will be subjected to DTCA, such as TV commercials presenting the merits of a certain product [1]. But consumers in countries that do not allow DTCA may still be subject to DTCl campaigns sponsored by pharmaceutical companies. For example, campaigns in Canada, the United Kingdom or the Netherlands may be televised, in-print or on the web with the aim of "raising awareness" for a

\footnotetext{
${ }^{1}$ Matthew Dear, “her Fantasy”, Label: Ghostly International - GI-156. Released June 4, 2012.
} 
particular disease [1,2]. With the advent of new media and social networks, DTCI and DTCA are now available far beyond the borders of permissive countries, reaching out to a larger audience than the local population [3]. Finally, the "direct" aspect pharmaceutically-sponsored communication reaches its zenith with in-person activities, taking place in non-clinical environments such as in restaurants, during which patients and pharmaceutical representatives mingle [4].

In this new song, Dear's core theme of love-seeking has been replaced by the fundamental issues of DTCA: patients' strong desire to have access to treatments that will relieve their symptoms and ideally cure them; their vulnerabilities when it comes to assessing commercial claims about certain products that may appear to either be miraculous, or specifically intended for them, due to informational asymmetry that favours companies over patients [5]; and the limited extent to which the informational aspect of DTCC really empowers patients when it may actually have the inverse effect of convincing them that a certain product is the solution to their health concerns $[1,6]$. While these issues can be discussed extensively and thoroughly in the scientific literature, their presentation in a song can help to give substance and clarity in order to enable understanding of their nature and extent, as well as to raise awareness about the pervasive effect of DTCC. Thus, the reader will be able to understand that DTCC may not have so much an informational purpose, but rather a promotional one in relation to a given product, and that motivations other than "care" are underlying such messages. In the song, DTCC is mainly presented through televised DTCA with references to frames that can refer to both the contours of a television and the images presented.

Hence, Dear's game of seduction is kindred to the promotional endeavour: both try to seduce by presenting a person with what s/he desires and fantasizes. The search for love by the former main character in Dear's song is analogous to the quest for "care" by a patient ${ }^{2}$, the latter confusing the actual purpose of advertisements (increasing a product's sales) with what is needed (search for an effective treatment) [1].

\section{Afterword}

The re-work of Dear's song is part of a genuine creative process in which, importantly, the reappropriation remains transparent and unambiguous. To acknowledge that fact, the title is a tribute to the original song: both the author's family name (Dear) and part of the title (by reusing the word "fantasy") have been included. This song arises from a real moment of creative joy in juggling with words and of restricting myself into a strict writing form, so as to create a new object - somewhat hybridized between research and art - evoking the sensitive side of my doctoral topic by the personification and the staging of ethical issues, while retaining rigour in the process and the final result.

Using arts to raise awareness about certain research results is an interesting way to push further their accessibility by presenting research in a more convenient and appealing format, shape, length and tone. We could therefore argue that art-based knowledge transfer (ABKT) allows the presentation of a complex issue without the need of scientific formalism. Performing ABKT requires a genuine creative process, so that the end-product (in this case, the song) as well as the intention are not instrumentalizing. In this context, the intention in the current work was not to claim that arts should be used for illustrating ethics; but rather that the arts have a much more important contribution, and one that is genuine and distinct [7]. The arts may even be a new way to perform research results by making the reader (or listener, if by chance this adaption of Dear's song were ever recorded) live the problem at stake through the aesthetics of the lyrics, and by presenting the issue with simplicity, and with some candor; something that is probably only possible for an object outside the formalism imposed by conventional scientific publication. The song is not only a means among others to disseminate the production of knowledge, it is also a unique way to experience the challenges of sharing knowledge by emphasizing the sensitive side of the rational.

\footnotetext{
${ }^{2}$ We could even add that it is analogous to biomedical research's quest for a cure, which is often performed through the search for a single drug to treat/cure patients, and seen as more desirable than other types of treatments.
} 


\section{References}

1. Bélisle-Pipon J-C, Williams-Jones B. Drug familiarization and therapeutic misconception via direct-to-consumer information. Journal of Bioethical Inquiry. 2015;12:259-67. doi:10.1007/s11673-015-9634-8.

2. Bélisle-Pipon J-C, Williams-Jones B. Regulating direct-to-consumer drug information: a case study of Eli Lilly's Canadian 40over40 erectile dysfunction campaign. Healthcare Policy. 2015;10:16-23. doi:10.12927/hcpol.2015.24209.

3. Bélisle-Pipon J-C, Williams-Jones B. Preparing for the arrival of Pink Viagra: the limits of direct-to-consumer information regulation. UNESCO Chair of Bioethics. 11th World Conference, Naples, Italy: 2015.

4. Bélisle-Pipon J-C. Dating patients': wrong for physicians but tolerated in the case of drug companies? 13th World Congress of Bioethics, Edinburgh, UK: 2016. doi:10.6084/m9.figshare.3792054.v1.

5. Bélisle Pipon J-C. De la binarité au modèle AI3R : la bioéthique écosystémique comme modèle d'analyse normative de l'industrie biopharmaceutique. Masters. Université de Montréal, 2013.

6. Bélisle-Pipon J-C, Williams-Jones B. Preparing for the arrival of "pink Viagra": strengthening Canadian direct-to-consumer information regulations. Canadian Medical Association Journal 2016;188:319-20. doi:10.1503/cmaj.150705.

7. Couture V, Bélisle-Pipon J-C, Laliberté M. Art + Bioéthique : quand la recherche en bioéthique quitte les murs de l'université. BioéthiqueOnline 2016;5/16. 